\title{
In Mexico, Cockfighting A Part of the Culture
}

\author{
Losada Hermenegildo R, Luna Lorena*, Rodríguez René, Cortés José, Vieyra Jorge E, Vargas Juan M and \\ Alemán Viridiana \\ Universidad Autónoma Metropolitana, Mexico
}

Submission: August 03, 2018; Published: August 13, 2018

*Corresponding author: Lorena Luna Rodríguez, Departamento de Biología de la Reproducción, Área de Sistemas de Producción Agropecuaria, Universidad Autónoma Metropolitana. San Rafael Atlixco No. 186, Col. Vicentina, Iztapalapa, 09340, Mexico, Email: llunaro@xanum.uam.mx

\author{
Abstract \\ Mexican gallistics provides cultural identity and has been preserved despite legal adversity and time; the symbolism of this, has strengthened \\ this activity and they are still valid among the mexican population.
}

Keywords: Palenque; Dramatization; Gambling; Symbolic; Social element; Roosters

\section{Introduction}

In Mexico the tradition of cockfighting is present in the states of Aguascalientes, Campeche, Chihuahua, State of Mexico, Hidalgo, Jalisco, Michoacan, Puebla, San Luis Potosi, Veracruz, Yucatan, Zacatecas and no state animal protection law establishes a prohibition for it [1]. The fights of roosters have different conceptions: sport, hobby, business or show, game of chance, bet, cultural and social element; and they are very controversial because they can generate passion or disapproval of the modern Mexican population [2,3]. So, it is not convenient to rate them; however, this activity is a social reality and widely spread.

\section{Combat Birds and the Fighting Spirit}

Since the combat birds and man began their interaction, the association has been made to the incitement in man of the need to fight until the last drop of blood is lost; for example, the Spartans showed young fighters fighting or brawling as an example of strength, courage and energy; as well as the unshakeable will to die rather than yield and seek victory regardless of the strength and power of the enemy [4].

\section{Origin and Genetic Selection}

There are two ancestors of combat roosters (oriental roosters and vankivoid roosters), from which the following lines originated: Albany, Claret, Hatch, Jumper, Kelso, Mel Sims, Radio, Regular Gray, Round Head and Sweater [5]. The love of fighting cocks was accompanied by the gradual improvement of breeding methods, the selection of the best roosters, the specialization of their coaches, the necessary tools and the modalities of the fights. The genetic selection criteria have been phenotypic: way to fight, won matches, non-aggressive animals with people, the color of legs, the bravura and the form of striking; however, each breeder chooses his animals according to the criteria under which he prefers to be identified in the "palenque".

\section{Rooster Fights in México}

Rooster fights are an acquired cultural feature, the origins of this activity are linked to the Spanish presence in America. However, the precise place of origin cannot be determined [4], nor the specific date of entry to the American continent; although it is affirmed that its appearance, adoption and diffusion date from the $16^{\text {th }}$ century. The historical roots refer that the fight between two trained roosters was brought to America by Hernán Cortés, who organized the first cockfight to impress the Aztec emperor Moctezuma in Tenochtitlán [2].

\section{Nationalist Folklore}

The cockfight is part of the culture in Mexico and has been transmitted from generation to generation; This gives the population a sense of identity and continuity, thus contributing to promoting respect for cultural diversity and human creativity. This activity is considered part of Mexican national folklore; since the image of the combat rooster has been culturally related to values such as bravery, gallantry, dedication, respect, honor, responsibility and loyalty; all of them linked to mexicanness and the defense of mexican ideals [1]. From the approach of Arias [6] the cockfight represents a cathartic phenomenon that is part of a broader civilizing process. It is also conferred a 
symbolism, which represents emotions, feelings and aspects of the human condition that hardly find release (relief) under other conditions or forms [7]. Geertzm [8] suggests that cockfighting is a dramatization of specific interests (the status level of the contenders), since superficially in a cockfight confronting two of these animals; but, they are men who compete (symbolically) for social prestige, which is seen in the system of bets that are made around the fight.

\section{The bets}

There are two types of bets: a) central bet, which is the one that is made between the owners of the roosters and is considered fair and egalitarian; and b) peripheral (multiple) bets, established among the attendees and considered unequal. The higher the central bet, the more balanced the fight, the greater the number of peripheral bets and the lower its inequality. Today the bets on roosters' fights are not considered reckless behavior (from the economic point of view), the risk is symbolic and what is put into play is the status (honor, dignity, respect) and prestige of the contenders in a momentary way $[3,8]$.

\section{Regulation}

In Mexico the cockfights had their peak in the seventeenth century, since then this activity has developed on the border of illegality; in 1690 a prohibition of cockfights was issued in Mexico City and Puebla, which was repealed in 1727. From 1974, these fights are regulated by the Federal Law of games and draws (regulation of organized gambling), requiring the permission of the secretary of government for the crossing of bets. Currently the activity has been reactivated in most of the states of the Republic and is part of the activities of the most important festivities in México (Aguascalientes and State of Mexico) [1].

\section{Intangible cultural heritage}

Due to the peculiarity of the cockfight, in Mexico it has been supported by the full permanent commission of the parliamentary groups [1], which has urged the secretary of culture to recognize Mexican gallistics as an element of intangible cultural heritage of Mexico and humanity. Being in the context of the "Convención para la salvaguardia del patrimonio cultural immaterial", where intangible cultural heritage is understood: the uses, representations, expressions, knowledge and techniques - together with the instruments, objects, artifacts and cultural spaces that are inherent to them - that communities, groups and in some cases, individuals recognize as an integral part of their cultural heritage.

\section{The cockfight}

The fight of roosters is made in the "palenque" mainly, which is a round area with wet sand in which the roosters fight, surrounded by a wooden circle that separates the roosters and tribunes, from where people observe and bet. The people who take a group of roosters to the fight, they are called "Partidos", those that participate in the weighing of the roosters to verify that they are in the same physical conditions the animals that will face, later they are placed a ring in a paw to guarantee the identity, which is inviolable. At the end of weighing the roosters the representative of the "Partido" deposits the money in cash with the treasurer, money that will be part of the prize package for the winner; then a draw is made to define the duels and their order. For the development of the duels a table judge and a sand judge are required, the first one certifies the weight of the cocks, the duration of the fights and the order of these; the second judge intervenes when the fight gets complicated, applies penalties for anomalies and orders the closing of the doors of the establishment at the beginning of the fight. When the fight is in progress the spectators shout to the rooster of their preference words of encouragement; after several minutes of fighting, one of the two roosters will die in combat or at the end of the established time the arena judge will declare a winner; the winning rooster sometimes survives, sometimes dies, just like the loser.

\section{References}

1. SIL (2017) Sistema de Información legislativa de la secretaria de Gobernación.

2. Pérez Z (1999) Su Majestad el gallo de pelea: Su cría, Edinova, México, pp. 340 .

3. Hawley F (1993) The Moral and Conceptual Universe of Cockfighters: Symbolism and Rationalization. Society and animals 1(2):159-168.

4. Sarabia M J (2006) Peleas de gallos en América. Su historia, tradición y actualidad. Noriega Editores, Madrid, Spain, pp. 212.

5. Fuentes M (2012) Aves de combate en el traspatio. Actas Iberoamericanas de Conservación Animal 2: 313-318.

6. Arias M D (2012) Setting Social Interaction into Motion: Theoretical Reflections on Play and Ethnographic Notes on Cockfights. Maguaré 26(2): 173-201.

7. Beeman W (1993) The Anthropology of Theater and Spectacle. Annual Review of Anthropology 22: 369-393.

8. Geertz C (1990) Descripción densa: hacia una teoría interpretativa de la cultura. In Geertz C, La interpretación de la cultura, Gedisa, Barcelona, pp. 387. 
(CC) Commons Attribution 4 This work is licensed under Creative BY DOI: 10.19080/GJAA.2018.05.555674
Your next submission with Juniper Publishers will reach you the below assets

- Quality Editorial service

- Swift Peer Review

- Reprints availability

- E-prints Service

- Manuscript Podcast for convenient understanding

- Global attainment for your research

- Manuscript accessibility in different formats ( Pdf, E-pub, Full Text, Audio)

- Unceasing customer service

Track the below URL for one-step submission https://juniperpublishers.com/online-submission.php 